\title{
Ecosystem-Based Management: Moving from Concept to Practice
}

\author{
Gonzalo Delacámara, Timothy G. O’Higgins, Manuel Lago, \\ and Simone Langhans
}

\begin{abstract}
Ecosystem-Based Management (EBM), intended to restore, enhance and/or protect the resilience of ecosystems, is gaining momentum. It is often argued, though, that some of the difficulties to provide practical guidance to conduct EBM stems from the lack of a clear definition. EBM emphasises on factoring in complex linkages in social-ecological systems; dealing with adequate scales (both time and space wise); promoting adaptive management of complex and dynamic systems; and adopting integrated assessment and management frameworks. This chapter shows, on one side, challenges to build consensus on a definition that is both conceptually and theoretically sound as well as practicable; on the other, the enabling factors that make EBM actually happen.
\end{abstract}

\section{Lessons Learned}

- Ecosystem-Based Management (EBM) moves away from a limited (partial) consideration of natural systems and society as separate entities.

- Society will face increasing levels of uncertainty-EBM is a more flexible approach that allows for the identification of some of those uncertainties, so

G. Delacámara $(\bowtie)$

IMDEA Water Institute, Alcalá de Henares, Madrid, Spain

e-mail: gonzalo.delacamara@imdea.org

T. G. O'Higgins

Marine and Renewable Energy Ireland (MaREI), Environmental Research Institute, University

College Cork (UCC), Cork, Ireland

e-mail: tim.ohiggins@ucc.ie

M. Lago

Ecologic Institute, Berlin, Germany

e-mail: Manuel.lago@ecologic.eu

S. Langhans

Department of Zoology, University of Otago, Dunedin, New Zealand

Basque Centre for Climate Change (BC3), Leioa, Spain

e-mail: simone.langhans@bc3research.org 
that they can be considered in decision-making, hence allowing society to adapt to error.

- EBM is a recognition of the need to "juggling all balls" at once. Since reality is complex, responses will also have to be so.

- EBM is an integrated approach in many different ways: acknowledging for the recognition of linkages between society and ecosystems, between different types of ecosystems, throughout time and space, looking at things from multiple standpoints.

- Enhanced governance is critical to make EBM happen. This is not just about transparency, accountability and meaningful social participation. It is also about using the right incentives, cooperating, coordinating decisions between sectors, improving our knowledge and information base, uptaking innovations, etc.

\section{Needs to Advance EBM}

- We need to better understand the complexity of the social, behavioural side of social-ecological systems, to match our understanding of the ecological side.

\section{Defining Ecosystem-Based Management: Minding Mice at a Crossroads or Not Quite?}

Ecosystem-Based Management (EBM) has gained increased popularity in recent years; yet, it has been argued that lack of consensus on its definition is precluding progress in terms of design and practical implementation of such approaches. EBM emphasises on considering ecosystem connections; dealing with appropriate spatial and temporal scales; fostering adaptive management of complex social-ecological systems; managing those systems in an integrated way; accounting for the dynamic nature of ecosystems and society, etc. There is no single agreed-upon definition for EBM, which sometimes is even referred to as the ecosystem approach (EA) itself. What seems common to all definitions, though, is the acknowledgement of the complexity and interspecies relationships within ecological systems, although broader governance elements are also of great importance in most definitions. This chapter does not develop a linguistic, nominal investigation of different definitions of EBM but rather aims at adding conceptual clarity while, at the same time, focusing on enabling factors for their effective uptake in decision- and policymaking for biodiversity and aquatic ecosystem services conservation.

We often demand clear-cut definitions: obvious, without any need of proof, unambiguous, unequivocal. However, demanding rigidly defined areas of doubt and uncertainty is a challenging exercise. Grasping at straws to some extent. Social-ecological systems such as aquatic ecosystems are highly adaptive and complex. How could one expect their management to be defined in an indisputable way if characterised by adaptability and complexity (Preiser et al. 2018)? Nonetheless, this is far from being a futile exercise since it also provides useful insights for 
the practical implementation of these management approaches (see Robinson and Culhane 2020 for further details on complexity, EBM and a framework to assess linkages).

\subsection{The Many-Sided Definition of Ecosystem-Based Management}

According to the outcomes of the AQUACROSS research project, ${ }^{1}$ EcosystemBased Management (EBM) can be understood (Gómez et al. 2016) as

any management or policy option intended to restore, enhance and/or protect the resilience of the ecosystem.

As such, EBM would stand for any course of action intended to improve the ability of an ecosystem to remain within critical thresholds, to respond to change, and/or to transform, so that a new equilibrium or a new evolutionary path follow (ibid.).

When applied to aquatic ecosystems, EBM can be said to set the foundations for effective and widely applicable management concepts and practices. Yet, one may think that EBM actually lacks a definition (and a universal 'grammar'), which may hinder implementation (Long et al. 2015, 2017; Willaert et al. 2019); that EBM requires extensive data and sophisticated modelling (Addison et al. 2019); that EBM is linked to naïve attempts to describe complex and adaptive systems, squeezing the universe between our fingers; and, on more practical grounds, that there are neither enough resources to deliver EBM approaches (Curtice et al. 2012) nor a clear mandate and institutional setup for EBM in prevailing legislation (Nilsson and Bohman 2015; Link et al. 2019). Harwell (2020) presents a non-exhaustive overview of the broad suite of U.S. federal environmental laws and regulations linked to ecosystem services and a survey of the legal scholar literature on the topic in the U.S. environmental law. The combined outcome of all these premises, whether utterly true or false, is definitely limiting the ability of EBM to deliver, let alone in aquatic ecosystems as shown in Langhans et al. (2018). As a matter of fact, EBM is often defined using combinations of underlying principles (Long et al. 2017). EBM aims at ensuring that choices do not negatively affect ecosystem functions, so that the delivery of aquatic ecosystem services and benefits stemming from them can be

\footnotetext{
${ }^{1}$ AQUACROSS was a Horizon 2020 project aimed to support EU efforts to protect aquatic biodiversity and ensure the provision of aquatic ecosystem services. As such, AQUACROSS sought to advance knowledge and application of ecosystem-based management (EBM) for aquatic ecosystems to support the timely achievement of the EU 2020 Biodiversity Strategy targets. AQUACROSS has received funding from the European Union's Horizon 2020 Programme for Research, Technological Development and Demonstration under Grant Agreement no. 642317.
} 


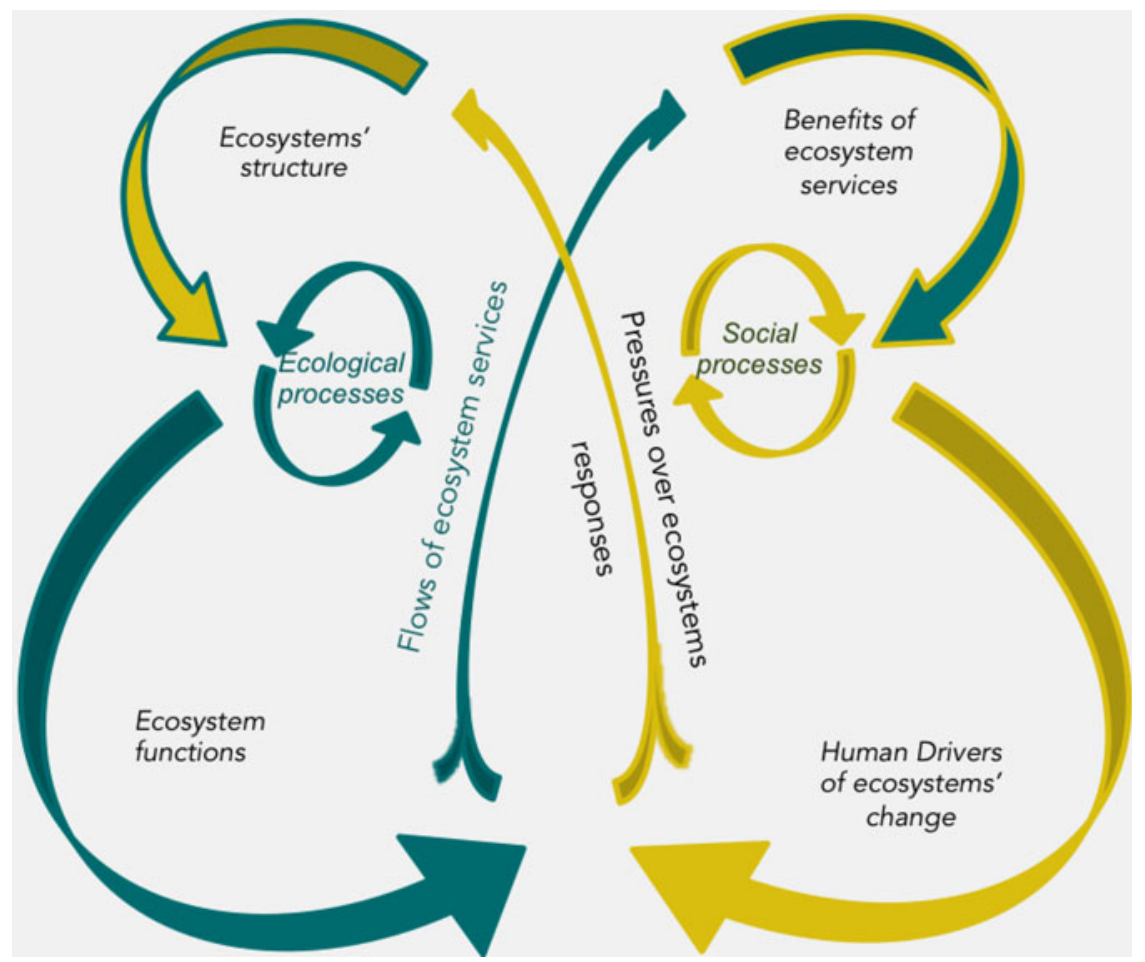

Fig. 1 Social-ecological systems as interlinked, complex, adaptive systems. Source: Gómez et al. (2016)

sustained in the long term. This makes EBM highly relevant to maintain and restore connections between social and ecological systems (Keesstra et al. 2018).

Social-ecological systems (SES) are therefore complex and adaptive systems that should be analysed in a holistic, integrated way (see Ostrom 2009). On the one hand, through the notion of SES, one can analyse the detrimental consequences over ecosystems that result from the satisfaction of multiple demands of services provided by nature and to society. As in Fig. 1 (see below), this could be seen as the demand side of the "butterfly" used to represent a SES. It shows how the demand and use of naturally provided services is an outcome of social processes, including markets and governing institutions, and determined by multiple factors (such as population and economic growth, climate change, technological progress, etc.). These demands of services result in pressures over ecosystems and further changes in their structure. On the other hand, one can analyse the potential of ecosystems to continue delivering ecosystem services on which human life, the social system and the ecological system itself depend upon, and how this all affects human wellbeing. This is the supply side, which if analysed can shed light on the functioning of ecosystems and how changes, induced by human actions, are linked to human wellbeing and sustainability.

EBM is also a way to address uncertainty and variability in ecological systems (Link et al. 2012) that, by definition are dynamic (DeFries and Nagendra 2017), in an 
attempt to embrace change, to learn from the past and to design and implement adaptive policies throughout the management process (Schultz et al. 2015). In other words, in the absence of sound governance frameworks and inclusive models (covering a wide range of social actors), EBM seems deemed flawed, as in the case of relevant sectoral policies such as the EU Common Agricultural Policy (Pe'er et al. 2019) or the Common Fishery Policy (Lado 2016). On the contrary, if properly designed and implemented, EBM rather shows the flexibility to identify uncertainties and incorporate those into decisions (through exploration of alternatives), and to adapt to error or uncertainty through an iterative review of progress toward the goal for which an EBM-based plan was developed.

By explicitly factoring in the full range of ecological and social interactions and processes necessary to sustain ecosystem structure, functions and services, EBM seems to offer great expectations for aquatic ecosystems management (Tallis et al. 2010; Langhans et al. 2018, 2019). One of the potential advantages of EBM is that, in principle, it should go well beyond conventional scientific and policy practice.

All dimensions of this multi-layered definition of EBM foster integration across ecological and social systems (Collins et al. 2011), explicitly address the need for sustainable patterns of resource use (Grehan et al. 2009), acknowledge interspecies relationships (Long et al. 2015), and call for the consideration of ecological thresholds and other environmental limits (Samhouri et al. 2017; Möllmann et al. 2015). Basing management decisions on the ecosystem entails that planning needs to be adapted to the dynamics of the whole ecosystem to at least preserve, if not to enhance, their potential to delivering services and benefits society depends upon.

Albeit difficult, describing is always simpler than analysing; defining may also be easier than understanding. Stefan Zweig, in Chess Story (Zweig 2011) said:

We are happy when people/things conform and unhappy when they don't. People and events don't disappoint us, our models of reality do. It is my model of reality that determines my happiness or disappointments.

It is critical to note that all definitions of EBM have some common features but mainly differ in their view of the connections between ecosystems and society, which has clear implications in terms of modelling (see Fulford et al. 2020 for a detailed discussion on mathematical modelling for EBM and ecosystem services).

\subsection{Disambiguation of the Concept}

There may be good reasons to believe that EBM does not add too much value if compared with the so-called ecosystem approach (EA), such as introduced by the Secretariat of the Convention on Biological Diversity (CBD 2008) (see Enright and Boteler 2020 for a deep review of the implicit origins of the approach and its subsequent adoption in marine International Law). As a matter of fact, a number of authors still use the latter expression rather than the former (Bennett et al. 2015; McIntyre 2019). According to CBD (ibid.) 
the ecosystem approach is a strategy for the integrated management of land, water and living resources that promotes conservation and sustainable use in an equitable way. Thus, the application of the ecosystem approach will help to reach a balance of the three objectives of the Convention: conservation; sustainable use; and the fair and equitable sharing of the benefits arising out of the utilization of genetic resources.

The EA can be considered as a management approach that takes the ecosystem itself as the relevant scale (time and space wise, but also on organisational grounds) but this can only be inferred from some of its 12 principles. For instance, principle 5 states:

conservation of ecosystem structure and functioning, in order to maintain ecosystem services, should be a priority target of the ecosystem approach.

Principle 6 in turn adds:

ecosystems must be managed within the limits of their functioning.

Finally, principle 7 stresses upon the fact that

the ecosystem approach should be undertaken at the appropriate spatial and temporal scales.

Beyond linguistic flourishes, the EA could certainly be considered an ecosystem approach to management, hence quite close to the notion of EBM, although other authors add some nuances (Kirkfeldt 2019). Do fine distinctions between these terms essentially matter? Not quite, within this context. . . One may actually argue that the EA does not preclude any other conservation approaches applied to aquatic ecosystems; hence, it may be compatible and consistent with such approaches, such as EBM (if considered a beast of a different coat), integrated water resources management (IWRM), integrated coastal zone management (ICZM), etc. In fact, these approaches may support the implementation of the EA in different biomes (Gómez et al. 2016).

As above, EBM emphasises on considering ecosystem connections (something that is actually coherent with the EA), dealing with adequate spatial and temporal scales, promoting adaptive management, deepening integration, accounting for the dynamic nature of ecosystems, etc. As in Sect. 1.1, there is no single agreed-upon, canonical definition for EBM, which sometimes is even referred to as the EA itself (Kirkfeldt, op. cit.).

Unlike the Common Classification of Ecosystem Services (CICES) (HainesYoung and Potschin 2018), for example, which was created ad hoc to homogenise a typology, not more than an accounting system, just as many other typologies, indicator sets, mapping exercises, databases, etc., this book is meant to shed light on available conceptual and management approaches, rather than to create a new 'taxonomy' of EBM definitions.

Further to the notions of EA and EBM, not more than a decade ago practitioners such as the International Union for the Conservation of Nature (Cohen-Shacham et al. 2016) and the World Bank (MacKinnon et al. 2008; Browder et al. 2019; Erin Gray et al. 2019) did coin the term Nature Based Solutions (NBS) (Davies and Lafortezza 2019), which has pervaded global discussions on water resources 
management since the release of the World Water Development Report 2018 (UNESCO 2018).

Some of those NBS, for instance, aim at restoring and conserving aquatic ecosystems via natural means. Those NBS can take the form of green infrastructures intended to maintain and enhance landscape, soil cover, and groundwater sources in order to improve their natural traits, the ecological services and other abiotic components they deliver, and to favour climate change adaptation and reduced vulnerability to extreme events and water quality degradation. The distinctive character of NBS would then have to do with their single purpose (i.e. conserving aquatic ecosystems), but also with a specific set of means (i.e. natural ones).

This example clearly underlines some distinctive features of NBS. On the one hand, not every solution that is effective on environmental grounds (e.g., increasing water recharge rates in groundwater bodies) is a NBS. On the other hand, NBS are interventions over ecosystems: they use natural processes rather than replacing nature, hence emulating ecological functions. It is also clear that, as in the case of the example above, the intended environmental outcome (i.e. recharging an aquifer) is not the end but the means that makes these NBS relevant for EBM of those aquatic ecosystems. Last but not least, it should also be mentioned that NBS are not simply means to reset a spoiled ecosystem to its pristine state, which is often not a feasible endeavour (if possible at all), but rather to adapt prevailing developments so as to enhance or to recover ecosystem functions that were either fragile or have been lost altogether.

As in EC (2015), NBS are

living solutions inspired by, continuously supported by and using nature, which are designed to address various societal challenges in a resource-efficient and adaptable manner and to provide simultaneously economic, social, and environmental benefits.

Maes and Jacobs (2017), in turn, add further conceptual clarity when defining NBS as

any transition to a use of ecosystem services with decreased input of non-renewable natural capital and increased investment in renewable natural processes.

Nesshöver et al. (2017) stress, though, that NBS need to be developed and discussed in relation to existing concepts to clarify their added value.

Along these lines, Integrated Water Resources Management (IWRM) can arguably be presented as an empirical concept more than a theoretical one (Smith and Clausen 2015). It was also built up from the actual experience of practitioners. The concept has now long been used (since the first global water conference, the United Nations -UN- Water Conference, in Mar del Plata, Argentina, on March 14th, 1977), even if practice is still limited to some areas of the world such as the European Union or Australia, to name a few. However, it was not until the UN Conference on Environment and Development (Rio, Brazil, 1992) that the concept was refined and became the object of wide discussions as to its practical implications. GWP (2000) states: 
IWRM is a process which promotes the co-ordinated development and management of water, land and related resources, in order to maximize the resultant economic and social welfare in an equitable manner without compromising the sustainability of vital ecosystems.

IWRM could therefore be seen as a wider notion, which could benefit from the design and implementation of EBM approaches.

Quite the same applies to Integrated Coastal Zone Management (ICZM). EC (2012), concerning the implementation of ICZM echoed the previous recognition of EC (2000) that coastal management lacked vision and was based on a very limited understanding of processes and dynamics in coastal ecosystems, as a result of the gap between scientific research and data collection, and end-users (see also Lewis et al. 2020 for a detailed review on the complexity and disparity of results from applying the existing coastal and estuarine ecosystem goods and services models and tools).

To cover the aquatic ecosystems continuum, Marine Spatial Planning (MSP, see Pauli 2010), has often been mentioned as an ecosystem-based approach. Through analysing and allocating parts of marine ecosystems to specific uses in order to meet ecological, economic, and social objectives, MSP integrates across economic sectors and among agencies, delivers adaptive approaches, and is focused on longer time frames. Le Tissier (2020), provides an insightful review on the relationship and contradictions regarding the juxtaposition of EBM and ICM and MSP.

IWRM and ICZM, let alone MSP, are all processes that entail a new fashion of governance, one that goes well beyond conventional and restrictive views based on integrity, stakeholder engagement, transparency and accountability or mere institutional reforms, and progresses towards mastering complexity, thus considering the redesign of incentives, horizontal and vertical coordination of sectoral policies, promoting innovation at different levels, etc. (such as in the OECD Water Governance Programme, for instance: OECD 2011).

Further to these conceptual approaches, a number of policy initiatives have sparked the development of a wide range of assessment frameworks and decision support systems for EBM (Harvey et al. 2017; Link and Browman 2017; Alexander and Haward 2019; Lago et al. 2019). Yet, a major challenge remains as to the design of an operational framework that links, in an efficient way, the assessment of biodiversity and ecological processes and their meaningful consideration in decision-making processes (and not just in policy making), despite recent progress (Langhans et al. 2018; Gómez et al. 2017; Do Yun et al. 2017). EBM faces both conceptual and functional limitations, in particular with regards to the lack of explicit acquaintance of the ecosystem services concept (Jordan et al. 2012), critical to connect ecological analyses with social wellbeing; a certain bias towards ecological dimensions rather than a balanced approach embedding social-ecological processes (Berkes 2012), which would enhance a more holistic understanding of relevant dynamics and feedback loops. Trade-offs, uncertainties, and non-linearities inherent in the management of aquatic ecosystems are somehow downplayed, when not overlooked at all (Curtin and Prellezo 2010; Culhane et al. 2020). 


\section{Distinctive Features of Ecosystem-Based Management of Aquatic Ecosystems}

Despite a certain amount of uncertainty and lack of conceptual clarity, there has been some evolution in the policy use of EBM (Gelcich et al. 2018). There is an actual policy need for a consolidated, practical definition of the term that addresses its different dimensions: understanding complex and adaptive social-ecological systems, resilience thinking (Curtin and Parker 2014), accounting for ecosystem functions and services, favouring multi-functional responses, etc.

EBM of aquatic ecosystems should therefore be assessed, designed and implemented so as to solve specific problems, and these solutions are often likely to maximise contributions to the resilience of social-ecological systems as a whole. Understanding the enabling conditions (see Sect. 3.3 of this chapter) that foster cooperative behaviour, or the factors that hinder it, is of chief importance for the design and implementation of EBM approaches. Progress in evolutionary theory (Di Marco et al. 2019; Wasser 2013) and game theory (Arfanuzzaman and Syed 2018; Punt et al. 2014) have been considered as particularly auspicious.

Identifying biodiversity policy challenges and assessing different alternatives to address them is far from being just a purely scientific or political endeavour. This daunting task requires both a conducive policy process and harnessing scientific knowledge to face stakeholders throughout with the outcomes of their own choices and to support them across the whole policy cycle. There is no such thing as good science or good policy: the former should address societal challenges; the latter, in turn, should be based on evidence.

Due to the complexities involved in aquatic social-ecological systems, it is clear there is neither a design of a one-size-fits-all EBM approach nor just one EBM implementation path. Additionally, it is critical to understand that more science may not necessarily close the existing knowledge gaps. Rather, each individual situation may need to be considered in its institutional and political setting and requires consideration of site-specific trade-offs.

Under an EBM approach science is neither only intended to inform nor to make technically feasible and sound decisions. It is rather a means to build a credible knowledge base through dialogue between stakeholders and scientists. Sharpe et al. (2020) provide more information on the benefits of Structure Decision MakingSDM and Decision Support Tools-DST in engaging with stakeholders and supporting decision makers; Lewis et al. (2020) also shed light on a communitybased decision support framework and tool for quantifying trade-offs in ecosystem goods and services.

It is often argued that EBM approaches are characterised by their contribution to ecological integrity, biodiversity, resilience and (in some versions, as in Granek et al. 2010 for coastal ecosystems) to ecosystem services delivery; by their use of scientific knowledge and appropriate spatial scales (Qiu et al. 2018), their acknowledgement of social-ecological connections, stakeholder engagement and accountability (Nunan et al. 2018); by transdisciplinarity and integrated management (Pires et al. 
2018; Carmen et al. 2018) and by their adaptiveness (Long et al. 2015). However, unlike common wisdom, EBM does not exclusively show those features and several approaches that are not based on the ecosystem may well do so.

What could be said to be specific of EBM for aquatic ecosystems?

- Holistic. EBM gives consideration to ecological and social factors, which demands interdisciplinary knowledge and prominence to water governance and the relationship among aquatic species as well as with their abiotic environment. EBM protects the integrity of aquatic ecosystems as a means to preserve a complementary array of ecosystem services as well as to preserve aquatic biodiversity in its own right. EBM thus acknowledges social-ecological interactions (necessarily including terrestrial ecosystems too) and seeks inclusive policy-making processes that favour transparency, accountability and provide a better framework so as to make different stakeholders understand why they make the decisions they make.

- Multi-functional. Unlike more conventional approaches to biodiversity and ecosystem conservation that focus on single benefits, EBM is characterised by multiple functions and benefits, thus being able to strike the balance, at once, between different policy domains. To put it in a different way, EBM aims at maximising the joint value of all aquatic ecosystem services and abiotic components, rather than focusing only on the delivery of single services, such as drinking water, water for irrigation, natural assimilation capacity of pollution, etc.).

- Based on evidence. Just like other management approaches, EBM is based on scientific knowledge. This is but solemnising what is obvious, though. What makes EBM stand out is the kind of scientific knowledge that is mobilised, as well as the way in which this is factored into decision-making processes. The role of science in EBM is two-fold: on one side, it is intended to be relevant for policy —and decision-making -; on the other, it is essential for the credibility of social knowledge and for the legitimacy of policy decisions it intends to inform and improve. Needless to say, in addition to scientific knowledge, traditional knowledge on ecosystem management (Joa et al. 2018) also provides critical insights.

- Mindful of the spatial scale (and ecological organisational levels). Management based on the aquatic ecosystem is much more challenging and sophisticated than managing single water bodies (or even watersheds). This might imply devolution to local communities, but may also require action at higher levels through, for example, transboundary or even global cooperation. EBM decisions are to take place at the appropriate level and scale, taking into account aquatic ecosystem boundaries but also complex interlinkages and adaptive processes. Actually, EBM keeps a close relationship with the notion of meta-ecosystem (Loreau et al. 2003). This 
concept provides a powerful theoretical tool to ascertain the emergent properties that arise from spatial coupling of local ecosystems, such as global source-sink dynamics, diversity-productivity patterns, stabilisation of ecosystem processes, and indirect interactions at landscape or regional scales.

- Across the water continuum. Not only complex interactions within the social-ecological system are considered, but also the relationships among aquatic realms (i.e. freshwater ecosystems, coastal ecosystems and transitional waters, marine ecosystems), including unknown and unpredictable effects.

- Calling for policy coordination. By definition, EBM calls for (horizontal across sectoral policies - and vertical - in multi-level governance systems, across different levels of government within the same sectoral policy -) policy coordination. As EBM requires cooperative agreements and collective action to share the range of aquatic ecosystem services obtained across different stakeholders and policy domains, and by seeking to balance ecological and social concerns, as above, these approaches open new opportunities of concurrently pursuing different policy objectives.

- Adaptive and dynamic. EBM is a way of adaptive management. Aquatic ecosystem processes and functions are complex and variable. Through acknowledging that there are no optimal solutions and that the future is uncertain, EBM seeks to build or strengthen adaptation capacities by restoring critical aquatic ecosystems and supporting social abilities to respond to a range of possible future scenarios. Low-hanging fruits of management interventions in the short term should be weighed against longer-term benefits of alternative actions. Uncertain events may alter long-term goals or show new, alternate lines of action. As a result of that, not only those aims but also management approaches to reach them should be regularly revisited, hence making monitoring critical so that indications of potential opportunities or difficulties are spotted sufficiently in advance.

\section{Enabling Factors for the Effective Uptake of Ecosystem-Based Management}

Beyond contributions to conceptual clarity, what seems more important is what makes EBM feasible, i.e. the enabling conditions for this kind of management approaches to happen in practice. Other chapters in this book (quote) will address some of those practical dimensions more specifically. In this chapter we discuss these factors from a conceptual point of view. 


\subsection{Moving Away from Conventional Praxis in Ecosystem Management}

It is very often the case that management toward a single goal often underestimates consequences or dependencies on other parts of ecosystems. For instance, traditional approaches to biodiversity conservation tend to focus on single pressures and specific impacts, flagship umbrella species (Kalinkat et al. 2017), hotspots (Marchese 2015), lack of integration of traditional and scientific knowledge (Sutherland et al. 2014). This is not to say that there is not utility in species-centred conservation approaches. Surrogate species remain popular as they provide useful and necessary shortcuts for some conservation programmes (Caro 2010). As a matter of fact, it is not only a question of the object of conservation programmes but rather about management approaches themselves. Those programmes achieve measurable outcomes (Herzon et al. 2018); however, positive results in the conservation of emblematic species may come at the expense of degrading resilience and increasing vulnerability.

From a management and policy perspective, conventional approaches are based on sectoral (and frequently conflicting) policies. On the contrary, EBM offers a promise of making the multiple co-benefits linked to the enhancement of the ecosystem overall visible. EBM opens new possibilities to meet different policy objectives simultaneously and quite often through cooperative approaches and policy synergies. The so-called nexus perspective is a good example of this (see Venghaus and Hake 2018, for an overview of nexus thinking in EU policies, or Zhang et al. 2018, for a specific application to hydropower generation).

Traditional ecosystem management approaches also tend to maximise the delivery of some ecosystem services (with a bias towards productive ones, such as drinking water, water for irrigation...) whilst impairing the ecosystem's capacity to deliver other services, including those linked to self-regulation and support. Traditional management has overreached in altering ecosystems for a single purpose. Emerging EBM, in contrast, finds opportunities in benefits stemming from the restoration of natural features. See, for instance, Sklar et al. (2019), where coastal risk reduction (i.e. storm protection through wave attenuation) and resilience (i.e. flood storage compensation schemes) come in the form of protection, enhancement and restoration of natural features such as mangroves, coral reefs, seagrass beds, sand dunes, inter-tidal and sub-tidal wetlands, mudflats, floodplains, salt marshes, etc.

An additional feature of conventional approaches is the neglect (to a very different extent) of the inherent uncertainties of social-ecological systems and the adoption of mostly deterministic approaches to future challenges when modelling the consequences of future scenarios. EBM necessarily separates from optimality (see Heal et al. 2001 for a seminal discussion on challenges posed by the transition from optimality to sustainability) and, through acknowledging irreducible uncertainties, emphasises on the relevance of building adaptability. The idea of building adaptation capacities, by the way, is far from being just one of restoring critical 
ecosystems (or ecosystem functions and processes), but also of strengthening social abilities (i.e. investing in social capital) to respond in a robust way to a range of possible futures.

In summary, EBM underlines the trade-offs between focusing on one single species, pressure, impact, sector, or ecosystem service, and adopting a more complex approach. In other words, EBM offers the possibility to discern between planning for the long-term or get caught in a series of lock-ins: technological, analytical, and institutional (Lukasiewicz et al. 2016), which clearly hinder adaptability.

\subsection{Adaptive Governance of Aquatic Ecosystems}

Schultz et al. (2015) defined governance as "the structures and processes by which people in societies make decisions and share power, creating the conditions for ordered rule and collective actions, or institutions of social coordination" (p. 7369). It is precisely the recognition of the above-mentioned lock-ins that supports the idea that ecosystems have to be governed. This implies, among other things, overcoming (impact) remedial, reactive, mostly unplanned, ad hoc approaches to ecosystem management in favour of pre-emptive, proactive, planned, collective, and coordinated decisions. To put it in a different way, EBM provides an opportunity for adaptive governance leading to higher social-ecological resilience (as Boyd et al. 2015 suggested).

There is a binding constraint for collective action, though: EBM is a leap in the dark or, at best, a chimera in the absence of a strong and enabling institutional setup (Börgström et al. 2015). As DeFries and Nagendra (2017) put it, ecosystem management is very much a "wicked problem", with no straightforward solution. Focusing on ecosystems rather than on single species or functions or processes requires defining specific spatial, temporal and organisational scales of ecosystem services provision. This, of course, has implications in turn for the appropriate scale and structure of ecosystem management institutions.

"Good governance" has gained momentum in the discussion about EBM (Long et al. 2015; Soma et al. 2015; Schultz et al. 2015; Gunderson et al. 2016; Bodin 2017; Bundy et al. 2017; Link et al. 2019). As Grindle (2010) pointed out,

good governance is a good idea. We would all be better off, and citizens of many developing countries would be much better off, if public life were conducted within institutions that were fair, judicious, transparent, accountable, participatory, responsive, well-managed, and efficient [...] Who, after all can reasonably defend bad governance? [...].

Good governance, though, carries a similar virus to EBM: the appeal of the idea somehow outpaces its capacity to deliver. It is sure-fire that EBM demands transparency, inclusiveness, a good knowledge base, the appropriate spatial scale, policy coordination, etc. Yet, aren't these defining characteristics of good public policy overall? 
An effective uptake of EBM requires adapting prevailing institutions and policymaking processes and jumping the fence to address challenges of a political nature.

Firstly, it is important to stress upon the idea that EBM is a means to an end. This entails that the objectives of EBM need to be defined and this requires the identification of what set of ecosystem services may be sustainably delivered as well as their relative importance. Beyond what Irvine et al. (2016) call shared values, it is a fact that there is a number of asymmetries (information, preferences, etc.) that explain why different individuals value ecosystem services in a different way (see Harwell et al. 2020 to deepen on the role of Strategic Communication in EBM for overcoming information asymmetries). Key to achieving mutually beneficial situations for biodiversity and ecosystem services is identifying those differences and trade-offs between users (Cavender-Bares et al. 2015, and also DeWittt et al. 2020 for a discussion on beneficiary-centric orientation supporting EBM). Indeed, what is special about EBM is that it gives prevalence to this collective choice, which makes everyone accountable for her or his own decisions.

Secondly, balancing trade-offs between ecosystem services and users requires finding the best way to meet pre-defined environmental objectives. This can be done through a number of alternatives. Choices between alternative courses of action are a collective endeavour, which also entails trade-offs: between short-term opportunity costs and long-term benefits, mitigated pressures and weaker provision of productive services or enhanced long-term water security, tackling critical events or managing risks and resilience, etc.

Foremost, seizing opportunities stemming from EBM demands a meaningful change of our mind-set. Whilst traditional measures are designed to respond to a particular challenge, EBM is linked, as above, to multiple ancillary benefits and may simultaneously contribute to various policy objectives, well beyond their intended outcome. The essence of EBM is precisely to be able to reap off the benefits of synergies across different ecological and policy realms. Nonetheless, current assessment methodologies such as optimisation models or cost-effectiveness analysis tend to be limited to account for multiple benefits, hence biasing decisions against EBM solutions, but also for uncertainty (Borgström et al. 2015), consideration of local trade-offs and disservices (Traoré et al. 2018), integration of ecosystem services in land and landscape planning and management (Turkelboom et al. 2018; GrêtRegamey et al. 2017; Arkema et al. 2015), non-linearities (Grêt-Regamey et al. 2014), and non-convexities (Hyytiäinen et al. 2015).

\section{Conclusion}

Most of us do not internalize that a social-ecological system is a complex entity, dynamic and adaptive both on ecological and social grounds. Virtually all readers would be willing to say they are perfectly aware of that assertion; some could even explain what it connotes beyond its primary or more literal meaning. Yet, most of us would overlook that evidence when making choices affecting ecosystems. Similar to 
our brain which has one side (left) that helps us think logically and organize thoughts to build sentences, and another one (right) that helps us experience emotions and interpret nonverbal cues, our way of approaching the management of socialecological systems responds in many ways to that dualism. As Kahneman (2011) would put it: we think fast and slow.

On the one hand, we feel driven to make decisions related to survival (i.e. withdrawing water from ecosystems for irrigation agriculture or drinking water supply). On the other, another part of us leads us to connection, complexity, and relationships. The key to progress in aquatic biodiversity and ecosystem conservation is to contribute, within the context of EBM, to both dimensions operating altogether. For the ecosystem to be genuinely healthy, all (specialized) elements of the social-ecological system must be integrated. That is, each element of the system has to perform its individual function while operating as part of the whole. Integration is neither more (but not less) than that: to bond different elements, already combined de facto (although sometimes they may have been disconnected, the reason why some interventions are aimed at restoring connectivity), so that the whole system works properly. Integration, inherent in EBM approaches, coordinates and balances those individual parts.

In recent decades, scientists from different disciplines have managed to develop assessment frameworks and even technologies that allow us to better understand the causal relationships between biological diversity and ecosystem services, between different types of ecosystem services, or between ecological processes and functions and social well-being (precisely through the notion of ecosystem services). However, none of them seems to guarantee that trends in biodiversity loss in aquatic ecosystems are reversed or that they are managed in a more integrated way. We have more information about aquatic ecosystems, somehow we know them better; yet, this does not always ensure that we understand how these complex and adaptive social-ecological systems do work.

Following the analogy regarding our brain, as above, one of the most relevant findings in scientific literature is the plasticity and ductile nature of our brain. The same applies to social-ecological systems to some extent: that is, they are systems that always change and not only at certain stages of their evolution. What modifies those systems? In essence, a series of experiences does. Depending on decisions and pressures on aquatic ecosystems, different parts of the ecosystem are activated and the way they do so to respond (as is also the case in social systems) determines the health of these socio-ecological systems and their level of biodiversity. Different connections then become more sophisticated and the system is reconfigured. There is some good news in that evidence: no social-ecological system, provided certain thresholds are not irreversibly exceeded, is a slave to each of these decisions and responses (both human and ecological). Thus, EBM approaches can intervene so that ecosystems become healthier and we result happier. The genetic diversity of aquatic ecosystems at stake plays an important role in how to respond to multiple pressures. However, as decisive or more than that genetic component is everything that happens in these social-ecological systems. In other words, beyond the basic 
'architecture' of ecosystems, it is our choices that truly determine whether socialecological systems evolve in a resilient and integrated way or not.

The integration inherent to the EBM concept precisely consists in facilitating the above-mentioned reconfigurations of social-ecological systems, in favouring the connections between the different parts of them. When these links are cooperative, the elements that integrate are created and strengthened.

\section{References}

Addison, P. F., Bull, J. W., \& Milner-Gulland, E. J. (2019). Using conservation science to advance corporate biodiversity accountability. Conservation Biology, 33(2), 307-318.

Alexander, K. A., \& Haward, M. (2019). The human side of marine ecosystem-based management (EBM): 'Sectoral interplay' as a challenge to implementing EBM. Marine Policy, 101, 33-38.

Arfanuzzaman, M., \& Syed, M. A. (2018). Water demand and ecosystem nexus in the transboundary river basin: A zero-sum game. Environment, Development and Sustainability, 20(2), 963-974.

Arkema, K. K., Verutes, G. M., Wood, S. A., Clarke-Samuels, C., Rosado, S., Canto, M., \& Faries, J. (2015). Embedding ecosystem services in coastal planning leads to better outcomes for people and nature. Proceedings of the National Academy of Sciences, 112(24), 7390-7395.

Bennett, E. M., Cramer, W., Begossi, A., Cundill, G., Díaz, S., Egoh, B. N., Geijzendorffer, R., et al. (2015). Linking biodiversity, ecosystem services, and human well-being: Three challenges for designing research for sustainability. Current Opinion in Environmental Sustainability, 14, $76-85$.

Berkes, F. (2012). Implementing ecosystem-based management: Evolution or revolution? Fish and Fisheries, 13(4), 465-476.

Bodin, Ö. (2017). Collaborative environmental governance: Achieving collective action in socialecological systems. Science, 357(6352), eaan1114.

Borgström, S., Bodin, Ö., Sandström, A., \& Crona, B. (2015). Developing an analytical framework for assessing progress toward ecosystem-based management. Ambio, 44(3), 357-369.

Boyd, E., Nykvist, B., Borgström, S., \& Stacewicz, I. A. (2015). Anticipatory governance for social-ecological resilience. Ambio, 44(1), 149-161.

Browder, G. J., Ozment, S., Rehberger, I., Gartner, T., \& Lange, G.-M. (2019). Integrating green and gray: Creating next generation infrastructure. Washington, DC: World Bank Group and World Resources Institute. Retrieved from http://documents.worldbank.org/curated/en/ 680391553111128576/Integrating-Green-and-Gray-Creating-Next-Generation-Infrastructure.

Bundy, A., Chuenpagdee, R., Boldt, J. L., de Fatima Borges, M., Camara, M. L., Coll, M., Diallo, I., Fox, C., Fulton, E. A., Gazihan, A., Jarre, A., Jouffre, D., Kleisner, K. M., Knight, B., Link, J., Matiku, P. P., Masski, H., Moutopoulos, D. K., Piroddi, C., Raid, T., Sobrino, I., Tam, J., Thiao, D., Torres, M. A., Tsagarakis, K., van der Meeren, G. I., \& Shin, Y.-J. (2017). Strong fisheries management and governance positively impact ecosystem status. Fish and Fisheries, 18(3), 412-439.

Carmen, E., Watt, A., Carvalho, L., Dick, J., Fazey, I., Garcia-Blanco, G., Grizzetti, B., Hauck, J., Izakovicova, Z., Kopperoinen, L., Liquete, C., Odeea, D., Steingröver, E., \& Young, J. (2018). Knowledge needs for the operationalisation of the concept of ecosystem services. Ecosystem Services, 29, 441-451.

Caro, T. (2010). Conservation by proxy: Indicator, umbrella, keystone, flagship, and other surrogate species. Washington, DC: Island Press.

Cavender-Bares, J., Polasky, S., King, E., \& Balvanera, P. (2015). A sustainability framework for assessing trade-offs in ecosystem services. Ecology and Society, 20(1), 17. 
Cohen-Shacham, E., Walters, G., Janzen, C., \& Maginnis, S. (2016). Nature-based solutions to address global societal challenges. Gland, Switzerland: IUCN. Retrieved from https://www. iucn.org/sites/dev/files/content/documents/nature-based_solutions_to_address_global_socie tal_challenges.pdf.

Collins, S. L., Carpenter, S. R., Swinton, S. M., Orenstein, D. E., Childers, D. L., Gragson, T. L., Grimm, N. B., Grove, M. J., Harlan, S. L., Kaye, J. P., Knapp, A. K., Kofinas, G. P., Magnuson, J. J., McDowell, W. H., Melack, J. M., Ogden, L. A., Robertson, G. P., Smith, M. D., Whitmer, A. C., \& Knapp, A. K. (2011). An integrated conceptual framework for long-term socialecological research. Frontiers in Ecology and the Environment, 9(6), 351-357.

Convention on Biological Diversity (CBD). (2008). UNEP/CBD/COP/DEC/IX/7 9 October 2008.

Culhane, F. E., Robinson, L. A., \& Lilleb $\varnothing$, A. I. (2020). Approaches for estimating the supply of ecosystem services: Concepts for ecosystem-based management in coastal and marine environments. In T. O'Higgins, M. Lago, \& T. H. DeWitt (Eds.), Ecosystem-based management, ecosystem services and aquatic biodiversity: Theory, tools and applications (pp. 105-126). Amsterdam: Springer.

Curtice, C., Dunn, D. C., Roberts, J. J., Carr, S. D., \& Halpin, P. N. (2012). Why ecosystem-based management may fail without changes to tool development and financing. Bioscience, 62, 508-515.

Curtin, CG., \& Parker, J.P. (2014). Foundations of resilience thinking. Conservation Biology, 28 (4), 912-923.

Curtin, R., \& Prellezo, R. (2010). Understanding marine ecosystem based management: A literature review. Marine Policy, 34(5), 821-830.

Davies, C., \& Lafortezza, R. (2019). Transitional path to the adoption of nature-based solutions. Land Use Policy, 80, 406-409.

DeFries, R., \& Nagendra, H. (2017). Ecosystem management as a wicked problem. Science, 356 (6335), 265-270.

DeWitt, T. H., Berry, W. J., Canfield, T. J., Fulford, R. S., Harwell, M. C., Hoffman, J. C., Johnston, J. M., Newcomer-Johnson, T. A., Ringold, P. L., Russel, M. J., Sharpe, L. A., \& Yee, S. J. H. (2020). The final ecosystem goods and services (FEGS) approach: A beneficiarycentric method to support ecosystem-based management. In T. O'Higgins, M. Lago, \& T. H. DeWitt (Eds.), Ecosystem-based management, ecosystem services and aquatic biodiversity: Theory, tools and applications (pp. 127-148). Amsterdam: Springer.

Di Marco, M., Harwood, T.D., Hoskins, A.J., Ware, C., Hill, S.L., Ferrier, S. (2019). Projecting impacts of global climate and land-use scenarios on plant biodiversity using compositionalturnover modelling. Global Change Biology.

Do Yun, S., Hutniczak, B., Abbott, J. K., \& Fenichel, E. P. (2017). Ecosystem-based management and the wealth of ecosystems. Proceedings of the National Academy of Sciences, 114(25), 6539-6544.

EC. (2000). Directive 2000/60/EC of the European Parliament and of the council establishing a framework for the community action in the field of water policy. OJ L 327, 22.12.2000, 1-73. Brussels: European Commission.

EC. (2012). COM (2012) 491 final, Progress of the EU's integrated maritime policy, SWD(2012) 255 final. Brussels: European Commission.

EC. (2015). Towards an EU research and innovation policy agenda for nature-based solutions \& re-Naturing cities. Final Report of the Horizon 2020 Expert Group on 'Nature-Based Solutions and Re-Naturing Cities'. Directorate-General for Research and Innovation Climate Action, Environment, Resource Efficiency and Raw Materials. Brussels: European Commission. Retrieved from https://ec.europa.eu/newsroom/horizon2020/document.cfm?doc_id=10195.

Enright, S. R., \& Boteler, B. (2020). The ecosystem approach in international law. In T. O'Higgins, M. Lago, \& T. H. DeWitt (Eds.), Ecosystem-based management, ecosystem services and aquatic biodiversity: Theory, tools, and applications (pp. 333-352). Amsterdam: Springer. 
Erin Gray, E., Ozment, S., Altamirano, J. C., Feltran-Barbieri, R., \& Morales, A. G. (2019). Greengray assessment: How to assess the costs and benefits of green infrastructure for water supply systems (Working paper). Washington, DC: World Resources Institute.

Fulford, R. S., Heymans, S. J. J., \& Wu, W. (2020). Mathematical modelling for ecosystem-based management (EBM) and ecosystem goods and services (EGS) assessment. In T. O'Higgins, M. Lago, \& T. H. DeWitt (Eds.), Ecosystem-based management, ecosystem services and aquatic biodiversity: Theory, tools and applications (pp. 275-290). Amsterdam: Springer.

Gelcich, S., Reyes-Mendy, F., Arriagada, R., \& Castillo, B. (2018). Assessing the implementation of marine ecosystem based management into national policies: Insights from agenda setting and policy responses. Marine Policy, 92, 40-47.

Gómez, C. M., Delacámara, G., Arévalo-Torres, J., Barbière, J., Barbosa, A. L., Boteler, B., Culhane, F., Daam, M., Gosselin, M.-P., Hein, T., Iglesias-Campos, A., Jähnig, S., Lago, M., Langhans, S., Martínez-López, J., Nogueira, A., Lillebø, A., O’Higgins, T., Piet, G., Pletterbauer, F., Pusch, M., Reichert, P., Robinson, L., Rouillard, J., \& Schlüter, M. (2016). The AQUACROSS innovative concept. Deliverable 3.1. AQUACROSS, European Union's Horizon 2020 Framework Programme for Research and Innovation Grant Agreement No. 642317. Technical Report (February 19th, 2016). European Union (H2020 FP Grant Agreement)-AQUACROSS. Retrieved from https://aquacross.eu/sites/default/files/D3.1\% 20Innovative\%20Concept.pdf.

Gómez, C. M., Delacámara G., Jähnig, S., Mattheiss, V., Langhans, S., Domisch, S.,Hermoso, V., Piet, G., Martínez-López, J., Lago, M., Boteler, B., Rouillard, J., Abhold, K., Reichert, P., Schuwirth, N., Hein, T., Pletterbauer, F., Funk, A., Nogueira, A., Lilleb $\varnothing$, A., Daam, M., Teixeira, H., Robinson, L., Culhane, F., Schlüter, M., Martin, R., Iglesias-Campos, A., Barbosa, A..L., Arévalo-Torres, J., \& O'Higgins, T. (2017). Developing the AQUACROSS assessment framework. Deliverable 3.2, AQUACROSS, European Union's horizon 2020 framework Programme for research and innovation Grant agreement no. 642317. Technical report. European Union (H2020 FP Grant agreement)-AQUACROSS. Retrieved from https:// aquacross.eu/sites/default/files/D3.2_Assessment\%20Framework.13012017.pdf.

Granek, E. F., Polasky, S., Kappel, C. V., Stoms, D. M., Reed, D. J., Primavera, E., Koch, W., Kennedy, C., Cramer, L. A., Hacker, S. D., Perillo, G. M. E., Aswani, S., Silliman, B., Bael, D., Muthiga, N., Barbier, E. B., \& Wolanski, E. (2010). Ecosystem services as a common language for coastal ecosystem-based management. Conservation Biology, 24, 207-216.

Grehan, A. J., van den Hove, S., Armstrong, C. W., Long, R., van Rensburg, T., Gunn, V., Mikkelsen, E., ben de Mol, B., \& Hain, S. (2009). HERMES: Promoting ecosystem-based management and the sustainable use and governance of deep-water resources. Oceanography, 22(1), 154-165.

Grêt-Regamey, A., Rabe, S. E., Crespo, R., Lautenbach, S., Ryffel, A., \& Schlup, B. (2014). On the importance of non-linear relationships between landscape patterns and the sustainable provision of ecosystem services. Landscape Ecology, 29(2), 201-212.

Grêt-Regamey, A., Altwegg, J., Sirén, E. A., van Strien, M. J., \& Weibel, B. (2017). Integrating ecosystem services into spatial planning - A spatial decision support tool. Landscape and Urban Planning, 165, 206-219.

Grindle, M. (2010). Good governance: The inflation of an idea. Faculty Research Working Paper Series, RWP 10-023, Harvard Kennedy School. Cambridge, Harvard University. Retrieved from https://dash.harvard.edu/handle/1/4448993.

Gunderson, A. R., Armstrong, E. J., \& Stillman, J. H. (2016). Multiple stressors in a changing world: The need for an improved perspective on physiological responses to the dynamic marine environment. Annual Review of Marine Science, 8, 357-378.

GWP. (2000). Integrated water resources management. TAC Background Paper No. 4. Stockholm: Global Water Partnership (GWP). Retrieved from https://www.gwp.org/globalassets/global/ toolbox/publications/background-papers/04-integrated-water-resources-management-2000english.pdf. 
Harvey, C. J., Kelble, C. R., \& Schwing, F. B. (2017). Implementing "the IEA": Using integrated ecosystem assessment frameworks, programs, and applications in support of operationalizing ecosystem-based management. ICES Journal of Marine Science, 74(1), 398-405.

Haines-Young, R., \& Potschin, M. B. (2018). Common international classification of ecosystem services (CICES) V5. 1 and guidance on the application of the revised structure. European Environment Agency (EEA). Retrieved from https://cices.eu/content/uploads/sites/8/2018/01/ Guidance-V51-01012018.pdf.

Harwell, D. R. (2020). Ecosystem services in U.S. environmental law and governance for the ecosystem-based management practitioner. In T. O’Higgins, M. Lago, \& T. H. DeWitt (Eds.), Ecosystem-based management, ecosystem services and aquatic biodiversity: Theory, tools, and applications (pp. 373-402). Amsterdam: Springer.

Harwell, M., Molleda, J. L., Jackson, C. A., \& Sharpe, L. (2020). Establishing a common framework for strategic communications in ecosystem-based management the natural sciences. In T. O'Higgins, M. Lago, \& T. H. DeWitt (Eds.), Ecosystem-based management, ecosystem services and aquatic biodiversity: Theory, tools, and applications (pp. 165-188). Amsterdam: Springer.

Heal, G., Daily, G. C., Ehrlich, P. R., \& Salzman, J. (2001). Protecting natural capital through ecosystem service districts. Stanford Environmental Law Journal, 20, 333.

Herzon, I., Birge, T., Allen, B., Povellato, A., Vanni, F., Hart, K., Radleyd, G., Tucker, G., Keenleyside, C., Oppermann, R., Underwood, E., Poux, X., Beaufoy, G., \& Pražan, J. (2018). Time to look for evidence: Results-based approach to biodiversity conservation on farmland in Europe. Land Use Policy, 71, 347-354.

Hyytiäinen, K., Ahlvik, L., Ahtiainen, H., Artell, J., Huhtala, A., \& Dahlbo, K. (2015). Policy goals for improved water quality in the Baltic Sea: When do the benefits outweigh the costs? Environmental and Resource Economics, 61(2), 217-241.

Irvine, K., O’Brien, N., Ravenscroft, L., Cooper, N., Everard, M., Fazey, I., Reed, M. S., \& Kenter, J. O. (2016). Ecosystem services and the idea of shared values. Ecosystem Services, 21, 184-193.

Joa, B., Winkel, G., \& Primmer, E. (2018). The unknown known - A review of local ecological knowledge in relation to forest biodiversity conservation. Land Use Policy, 79, 520-530.

Jordan, S. J., O'Higgins, T., \& Dittmar, J. A. (2012). Ecosystem services of coastal habitats and fisheries: Multiscale ecological and economic models in support of ecosystem-based management. Marine and Coastal Fisheries, 4(1), 573-586.

Kahneman, D. (2011). Thinking, fast and slow. Macmillan.

Kalinkat, G., Cabral, J. S., Darwall, W., Ficetola, G. F., Fisher, J. L., Giling, D. P., Gosselin, M.-P., Grossart, H. P., Jähnig, S. C., Jeschke, J. M., Knopf, K., Larsen, S., Onandia, G., Pätzig, M., Saul, W.-C., Singer, G., Sperfeld, E., \& Jarić, I. (2017). Flagship umbrella species needed for the conservation of overlooked aquatic biodiversity. Conservation Biology, 31(2), 481-485.

Keesstra, S., Nunes, J., Novara, A., Finger, D., Avelar, D., Kalantari, Z., \& Cerdà, A. (2018). The superior effect of nature based solutions in land management for enhancing ecosystem services. Science of the Total Environment, 610, 997-1009.

Kirkfeldt, T. S. (2019). An ocean of concepts: Why choosing between ecosystem-based management, ecosystem-based approach and ecosystem approach makes a difference. Marine Policy, 106, 103541.

Lado, E. P. (2016). The common fisheries policy: The quest for sustainability. New York: Wiley.

Lago, M., Boteler, B., Rouillard, J., Abhold, K., Jähnig, S., Iglesias-Campos, A., Delacámara, G., Piet, G., Hein, T., Nogueira, A., Lilleb $\varnothing$, A., Strosser, P., Robinson, L., De Wever, A., O’Higgins, T., Schlüter, M., Török, L., Reichert, P., van Ham, C., Villa, F., \& McDonald, H. (2019). Introducing the H2020 AQUACROSS project: Knowledge, assessment, and management for AQUAtic biodiversity and ecosystem services aCROSS EU policies. Science of the Total Environment, 652, 320-329.

Langhans, S. D., Domisch, S., Balbi, S., Delacámara, G., Hermoso, V., Kuemmerlen, M., Martin, R., Martínez-López, J., Vermeiren, P., Ferdinando Villa, F., \& Jähnig, S. C. (2018). Combining 
eight research areas to foster the uptake of ecosystem-based management in fresh waters. Aquatic Conservation: Marine and Freshwater Ecosystems, 29(7), 1161-1173.

Langhans, S. D., Jähnig, S. C., Lago, M., Schmidt-Kloiber, A., \& Hein, T. (2019). The potential of ecosystem-based management to integrate biodiversity conservation and ecosystem service provision in aquatic ecosystems. Science of the Total Environment, 672, 1017-1020.

Le Tissier, M. (2020). Unravelling the relationship between ecosystem-based management, integrated coastal zone management and marine spatial planning. In T. O'Higgins, M. Lago, \& T. H. DeWitt (Eds.), Ecosystem-based management, ecosystem services and aquatic biodiversity : Theory, tools, and applications (pp. 403-416). Amsterdam: Springer.

Lewis, N. S., Marois, D. E., Littles, C. J., \& Fulford, R. S. (2020). Projecting changes to coastal and estuarine ecosystem goods and services - Models and tools. In T. O'Higgins, M. Lago, \& T. H. DeWitt (Eds.), Ecosystem-based management, ecosystem services and aquatic biodiversity: Theory, tools, and applications (pp. 235-254). Amsterdam: Springer.

Link, J. S., \& Browman, H. I. (2017). Operationalizing and implementing ecosystem-based management. ICES Journal of Marine Science, 74(1), 379-381.

Link, J. S., Ihde, T. F., Harvey, C. J., Gaichas, S. K., Field, J. C., Brodziak, J. K. T., Towsend, H. M., \& Peterman, R. M. (2012). Dealing with uncertainty in ecosystem models: The paradox of use for living marine resource management. Progress in Oceanography, 102, 102-114.

Link, J. S., Dickey-Collas, M., Rudd, M., McLaughlin, R., Macdonald, N. M., Thiele, T., \& Rae, M. (2019). Clarifying mandates for marine ecosystem-based management. ICES Journal of Marine Science, 76(1), 41-44.

Long, R. D., Charles, A., \& Stephenson, R. L. (2015). Key principles of marine ecosystem-based management. Marine Policy, 57, 53-60.

Long, R. D., Charles, A., \& Stephenson, R. L. (2017). Key principles of ecosystem-based management: The fishermen's perspective. Fish and Fisheries, 18(2), 244-253.

Loreau, M., Mouquet, N., \& Holt, R. D. (2003). Meta-ecosystems: A theoretical framework for a spatial ecosystem ecology. Ecology Letters, 6(8), 673-679.

Lukasiewicz, A., Pittock, J., \& Finlayson, M. (2016). Institutional challenges of adopting ecosystem-based adaptation to climate change. Regional Environmental Change, 16(2), 487-499.

MacKinnon, K., Sobrevila, C., \& Hickey, V. (2008). Biodiversity, climate change, and adaptation: Nature-based solutions from the World Bank portfolio. Washington, DC: World Bank. Retrieved from http://documents.worldbank.org/curated/en/149141468320661795/Biodiver sity-climate-change-and-adaptation-nature-based-solutions-from-the-World-Bank-portfolio.

Maes, J., \& Jacobs, S. (2017). Nature-based solutions for Europe's sustainable development. Conservation Letters, 10(1), 121-124.

Marchese, C. (2015). Biodiversity hotspots: A shortcut for a more complicated concept. Global Ecology and Conservation, 3, 297-309.

McIntyre, O. (2019). Environmental protection and the ecosystem approach. In S. C. McCaffrey, C. Leb, \& R. T. Denoon (Eds.), Research handbook on international water law (pp. 126-146). Cheltenham: Edward Elgar Publishing.

Möllmann, C., Folke, C., Edwards, M., \& Conversi, A. (2015). Marine regime shifts around the globe: Theory, drivers and impacts. Philosophical Transactions of the Royal Society, B370, 20130260.

Nesshöver, C., Assmuth, T., Irvine, K. N., Rusch, G. M., Waylen, K. A., Delbaere, B., et al. (2017). The science, policy and practice of nature-based solutions: An interdisciplinary perspective. Science of the Total Environment, 579, 1215-1227.

Nilsson, A. K., \& Bohman, B. (2015). Legal prerequisites for ecosystem-based management in the Baltic Sea area: The example of eutrophication. Ambio, 44(3), 370-380.

Nunan, F., Menton, M., McDermott, C., \& Schreckenberg, K. (2018). Governing for ecosystem health and human wellbeing. In K. Schreckenberg, G. Mace, \& M. Poudyal (Eds.), Ecosystem services and poverty alleviation (pp. 159-173). Oxon: Routledge. 
OECD. (2011). Water governance in OECD Countries: A multi-level approach. Paris: OECD Publishing. Retrieved from https://doi.org/10.1787/9789264119284-en.

Ostrom, E. (2009). A general framework for analyzing sustainability of social-ecological systems. Science, 325(5939), 419-422.

Pauli, G. A. (2010). The blue economy: 10 years, 100 innovations, 100 million jobs. New Mexico: Paradigm Publications.

Pe'er, G., Zinngrebe, Y., Moreira, F., Sirami, C., Schindler, S., Müller, R., Bontzorlos, V., Clough, D., Bezák, P., Bonn, A., Hansjürgens, B., Lomba, A., Möckel, S., Passoni, G., Schleyer, G., Schmidt, J., \& Lakner, S. (2019). A greener path for the EU common agricultural policy. Science, 365(6452), 449-451.

Pires, A. P., Srivastava, D. S., \& Farjalla, V. F. (2018). Is biodiversity able to buffer ecosystems from climate change? What we know and what we don't. Bioscience, 68(4), 273-280.

Preiser, R., Biggs, R., De Vos, A., \& Folke, C. (2018). Social-ecological systems as complex adaptive systems: Organizing principles for advancing research methods and approaches. Ecology and Society, 23(4), 46.

Punt, M. J., Weikard, H. P., \& van Ierland, E. C. (2014). Game theory and marine protected areas: The effects of conservation autarky in a multiple-use environment. In P. A. L. D. Nunes, P. Kumar, \& T. Dedeurwaerdere (Eds.), Handbook on the economics of ecosystem services and biodeversity (pp. 264-277). Cheltenham: Edward Elgar.

Qiu, J., Carpenter, S. R., Booth, E. G., Motew, M., Zipper, S. C., Kucharik, C. J., Loheide, S. P., II, \& Turner, M. G. (2018). Understanding relationships among ecosystem services across spatial scales and over time. Environmental Research Letters, 13(5), 054020.

Robinson, L. A., \& Culhane, F. E. (2020). Linkage frameworks: An exploration tool for complex systems in ecosystem-based management. In T. O'Higgins, M. Lago, \& T. H. DeWitt (Eds.), Ecosystem-based management, ecosystem services and aquatic biodiversity: Theory, tools, and applications (pp. 213-234). Amsterdam: Springer.

Samhouri, J. F., Andrews, K. S., Fay, G., Harvey, C. J., Hazen, E. L., Hennessey, S. M., Holsman, K., Hunsicker, M. E., Large, S. I., Marshall, K. N., Stier, A. C., Tam, J. C., \& Zador, S. G. (2017). Defining ecosystem thresholds for human activities and environmental pressures in the California current. Ecosphere, 8(6), e01860.

Schultz, L., Folke, C., Österblom, H., \& Olsson, P. (2015). Adaptive governance, ecosystem management, and natural capital. Proceedings of the National Academy of Sciences, 112(24), 7369-7374.

Sharpe, L., Hernandez, C., \& Jackson, C. (2020). Prioritizing stakeholders, beneficiaries and environmental attributes: A tool for ecosystem-based management. In T. O’Higgins, M. Lago, \& T. H. DeWitt (Eds.), Ecosystem-based management, ecosystem services and aquatic biodiversity: Theory, tools and applications (pp. 189-212). Amsterdam: Springer.

Sklar, F. H., Meeder, J. F., Troxler, T. G., Dreschel, T., Davis, S. E., \& Ruiz, P. L. (2019). The Everglades: At the forefront of transition. In E. Wolanski, J. W. Day, M. Elliott, \& R. Ramachandran (Eds.), Coasts and estuaries (pp. 277-292). Amsterdam: Elsevier.

Smith, M., \& Clausen, T. (2015). Integrated water resource management: A new way forward. Marseille: World Water Council (WWC).

Soma, K., van Tatenhove, J., \& van Leeuwen, J. (2015). Marine governance in a European context: Regionalization, integration and cooperation for ecosystem-based management. Ocean \& Coastal Management, 117, 4-13.

Sutherland, W. J., Gardner, T. A., Haider, L. J., \& Dicks, L. V. (2014). How can local and traditional knowledge be effectively incorporated into international assessments? Oryx, 48(1), $1-2$.

Tallis, H., Levin, P. S., Ruckelshaus, M., Lester, S. E., McLeod, K. L., Fluharty, D. L., \& Halpern, B. S. (2010). The many faces of ecosystem-based management: Making the process work today in real places. Marine Policy, 34(2), 340-348. 
Traoré, S., Salles, J.M., Tidball, M. (2018). Ecosystem services, ecosystem disservices, and economic dynamics: Is it always worth to conserve natural capital? Retrieved from https:// pdfs.semanticscholar.org/aeb2/d9f6876c0b32c2bfa6597662272bae8a1c93.pdf.

Turkelboom, F., Leone, M., Jacobs, S., Kelemen, E., García-Llorente, M., Baró, F., Termansenh, M., Barton, D. N., Berry, P., Stange, E., Thoonen, M., Kalóczkaik, A., Vadineanu, A., Castro, A. J., Czúczk, B., Röckmann, C., Wurbs, D., Odee, D., Preda, E., Gómez-Baggethun, E., Rusch, G. M., Martínez, G., Palomo, I., Dick, J., Casaera, J., van Dijk, J., Priess, J. A., Langemeyer, J., Mustajoki, J., Kopperoinen, L., Baptist, M. J., Peri, P. L., Mukhopadhyay, R., Aszalós, R., Roy, S. B., Luque, S., \& Rusch, V. (2018). When we cannot have it all: Ecosystem services trade-offs in the context of spatial planning. Ecosystem Services, 29, 566-578.

UNESCO. (2018). United Nations world water assessment programme. The United Nations world water development Report 2018: Nature-based solutions for water. Paris: UNESCO. Retrieved from https://unesdoc.unesco.org/ark:/48223/pf0000261424.

Venghaus, S., \& Hake, J. F. (2018). Nexus thinking in current EU policies-the interdependencies among food, energy and water resources. Environmental Science \& Policy, 90, 183-192.

Wasser, S.P. (Ed.). (2013). Evolutionary theory and processes: Modern horizons: Papers in honour of Eviatar Nevo. Berlin: Springer.

Willaert, T., Garcia-Alegre, A. G., Queiroga, H., Cunha e Sá, M. A., \& Lillebø, A. I. (2019). Measuring vulnerability of marine and coastal habitats' potential to deliver ecosystem services: Complex Atlantic region as case study. Frontiers in Marine Science, 6, 199.

Zhang, C., Chen, X., Li, Y., Ding, W., \& Fu, G. (2018). Water-energy-food nexus: Concepts, questions and methodologies. Journal of Cleaner Production, 195, 625-639.

Zweig, S. (2011). Chess story. New York: New York Review of Books.

Open Access This chapter is licensed under the terms of the Creative Commons Attribution 4.0 International License (http://creativecommons.org/licenses/by/4.0/), which permits use, sharing, adaptation, distribution and reproduction in any medium or format, as long as you give appropriate credit to the original author(s) and the source, provide a link to the Creative Commons licence and indicate if changes were made.

The images or other third party material in this chapter are included in the chapter's Creative Commons licence, unless indicated otherwise in a credit line to the material. If material is not included in the chapter's Creative Commons licence and your intended use is not permitted by statutory regulation or exceeds the permitted use, you will need to obtain permission directly from the copyright holder.

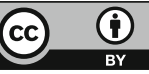

